\title{
Use of Androgens in Postmenopausal Women
}

\author{
Renata Britto $^{\mathrm{a}, \mathrm{c}}$, Leila Araujo ${ }^{\mathrm{b}}$
}

\begin{abstract}
During menopause, women may experience greater loss of bone mineral density, leading to a high risk of fractures. Estradiol has great importance in the maintenance of bone micro architecture and estradiol and testosterone combination have high effectiveness in preventing osteoporosis and fractures in post menopausal women. There is an actual trend of using testosterone combined with estradiol in order to improve the hypo androgen symptoms with an important improvement in the quality of life of these women. The behavior of the lipid profile in women using this combination is not well defined once the results of the studies already made are very controversial. This review article aims at evaluating the studies made in the last years that evaluated the impact of the use of androgens in post menopause women over a bone mineral density and the lipid profile. Searches of articles were made on Pubmed from 1980 to 2011. The searches were made with the use of the keywords 'testosterone' or 'androgens' and 'postmenopausal women' and 'bone density' and 'hormone replacement therapy'. In its second phase the 'testosterone' or 'androgens' and 'postmenopausal women' and 'lipoprotein' and 'hormone replacement'. A total of 67 articles were found. After reading their whole content, 09 original articles were included in this review, prospective that evaluated bone mineral density or the lipid profile in patients using hormone therapy in post menopause. The benefits of the use of androgens have been demonstrated in publications resulting from studies with a reduced number of patients, in non-probabilistic samples, and most of them
\end{abstract}

Manuscript accepted for publication December 12, 2011

${ }^{\mathrm{a} D e p a r t m e n t ~ o f ~ G y n e c o l o g y, ~ F e d e r a l ~ U n i v e r s i t y ~ o f ~ B a h i a ~(U F B A), ~}$ Salvador, Bahia, Brazil

${ }^{b}$ Department of Endocrinology, Federal University of Bahia (UFBA), Salvador, Bahia, Brazil

${ }^{\mathrm{c} C}$ Corresponding author: Renata Britto, Augusto Viana, s/n, Canela, zip code: 40110-060, Salvador, Bahia, Brazil.

Email: renatalopesbritto@gmail.com

doi:10.4021/jem56w observational. On the other hand, the results converge towards an improvement of the lipid profile and increase in the bone mineral density in the patients in post menopause. The greater limitation of these results lies on the difficulty on determining the isolated effects of the androgens once the studies showed results obtained through HT with estradiol and androgens. Clinical rehearsals in comparison between the use of isolated estradiol and estardiol + testosterone shall clarify the impact of this combination under the lipid profile and bone protection in postmenopausal patients.

Keywords: Testosterone; Postmenopausal women; Lipoprotein; Hormone replacement therapy; Androgens; Bone mineral density

\section{Introduction}

Due to the increase in number of women who survive on average one-third of their lives after menopause, osteoporosis has become a condition of high cost to society. During menopause, women may experience greater loss of bone mineral density, leading to a high risk of fractures and their consequences for patients in this stage of life. Estradiol (E) has great importance in the maintenance of bone micro architecture and $\mathrm{E}$ and testosterone $\mathrm{T}$ ) combination have high effectiveness in preventing osteoporosis and fractures in post menopausal women [1].

Women at menacme have a natural protection against cardiovascular diseases [2-5]. Until the middle of the last decade, hormone therapy (HT) was indicated for cardiovascular protection and many observational studies showed an improvement in the lipid profile and reduction in cardiovascular risks among users of HT [6-9].

In the last decade studies suggest that HT in post menopause with a combined scheme of estrogen and progestogen not only does not show any protection against cardiovascular diseases, but also seems to promote the increase on the risk of acute myocardial infarction and cerebrovascular accident [10-12]. Whereas some studies show that menopause causes a worsening in the lipid profile of women, the use of E combined with progesterone has shown a worsening in the lipid profile with an increase in the LDL cholesterol (LDL) and 
in the cardiovascular risk $[13,14]$. There is an actual trend of using $\mathrm{T}$ combined with $\mathrm{E}$ in order to improve the hypo androgen symptoms with an important improvement in the quality of life of these women [15-18]. Studies have already shown that this combination offers endometrial protection, without the use of progestogens needed [19]. The behavior of the lipid profile in women using the combination $\mathrm{E}$ and $\mathrm{T}$ is not well defined once the results of the studies already made are very controversial [20-25].

\section{Subjects and Methods}

\section{Objectives}

This review article aims at evaluating the studies made in the last years that evaluated the impact of the use of androgens in HT on women in post menopause over a bone mineral density and the lipid profile.

\section{Review methods}

In July, 2011 searches were made on Pubmed and the articles searched were the one published between 1980 and 2011. The searches were made with the use of the keywords 'testosterone' and 'postmenopausal women' and 'bone density' and 'hormone replacement therapy' and 12 articles were found. The search was made exchanging the term 'testosterone' for 'androgens' and 19 more articles were found.

In its second phase the 'testosterone' and 'postmenopausal women' and 'lipoprotein' and 'hormone replacement therapy' were used and 14 articles were found. The search was made exchanging the term 'testosterone' for 'androgens' and 22 more articles were found.

\section{Review Results}

A total of 67 articles were found. There were 25 duplicated articles and those were excluded. From these results after reading the title, 19 articles, which did not deal with postmenopausal patients using HT, were excluded. 02 articles were the result of studies in vitro with the use of sexual hormones. 09 were review articles. 03 dealt with sexual esteroid analysis in men and women. 01 study was about rheumatoid arthritis in the post menopause. 01 article talked about obesity and the sexual hormones. 01 article evaluated the action of HT upon the hippocampus and 01 article was about the action of hormones on the cerebral vessels. 01 article evaluated the risk of breast cancer while using HT.

After reading the abstract the 23 remaining articles, 09 were excluded for not dealing with articles evaluating HT in postmenopausal women. 03 articles evaluated the risk of diabetis and resistance to insulin in postmenopausal women.
03 articles evaluated the use of non-hormonal therapy in post menopause. And 03 others dealt with the use of Raloxifeno, smoking and bone density and aromatase in patients in post menopause.

Among the 14 remaining articles, after reading their whole content, 09 original articles were included in this review, prospective that evaluated bone mineral density or the lipid profile in patients using hormone therapy in post menopause.

\section{Discussion}

The benefits over bones were demonstrated in some recent studies with the increase of bone mineral density among users of the combination $\mathrm{E}+\mathrm{T}[26,27]$. The use of $\mathrm{T}$ seems to increase even more the bone mineral density in relation to the isolated use of $\mathrm{E}[28,29]$.

Britto, et al studied 61 Brazilian patients in prospective cohort study using implants of E and T. BMD assessment through Dual energy X-ray absorptiometry showed addition of $1.87 \%$ in the lumbar spine and $3.8 \%$ in the neck of femur BMD in women using impants, and decrease in BMD lumbar of $5.92 \%$, and $5.06 \%$ in the neck of femur, without implants, after 1 year [1].

In a study taken in London with 364 women in post menpause, Garnett et al showed diference in the digital radiography of 1123 grams of hydroxyapatite $(\mathrm{gHa}) / \mathrm{cm}^{2}$ in the group treated with $75 \mathrm{mg}$ of $\mathrm{E}$ and $100 \mathrm{mg}$ of endodermic $\mathrm{T}$ versus $0951 \mathrm{gHa} / \mathrm{cm}^{2}$ in the control group [26].

Studd et al studied 213 patients using E implants of E (75 mg) and $\mathrm{T}(100 \mathrm{mg})$ and showed an increase of $8.3 \%$ and $2.8 \%$ in bone density and lumbar spine and femoral neck after 1 year [27].

Davis et al showed that use of T potentialized the effects of $\mathrm{E}$ on bone density in prospective study of 2 years with 34 Australian women in post menopause using implants of 50 $\mathrm{mg}$ of $\mathrm{E}$ or $\mathrm{E}+\mathrm{T}(50 \mathrm{mg})$. A bone densitometry (DEXA) was carried out with an increase of $10 \%$ and $8.8 \%$ in bone density in the femur and lumbar spine (L1-L4) in the group using $\mathrm{E}+\mathrm{T}$, compared to $2.4 \%$ and $3.5 \%$ in the group using isolated $\mathrm{E}$ [29].

Savvas et al studying 20 Londoner women using oral E in post menopause, inserted implants of $\mathrm{E}+\mathrm{T}$ in 10 patients and observed an increase of $5.7 \%$ of bone density in lumbar spine and $5.2 \%$ in femoral neck of these women, through the bone mineral densitometry (DEXA) after 1 year. In women who kept using oral isolated $\mathrm{E}$ there were no changes in bone density [28].

Castelo-Branco et al studied 120 patients in Barcelona, Spain, using the E valerate $4 \mathrm{mg}$ and $200 \mathrm{mg}$ of intramuscular enanthate of dihydroepiandrosterone month and after 1 year an increase of $16.9 \%$ was found in the total cholesterol (TC), $8 \%$ in the LDL, $6.5 \%$ in the triglycerides (TG) and 
reduction of $2.7 \%$ in HDL cholesterol (HDL) [30].

Zang, $\mathrm{H}$. et al published a Swidish study taken on 63 patients, followed for 3 months using $\mathrm{E}$ valerate $2 \mathrm{mg} /$ day or valerate $\mathrm{E} 2 \mathrm{mg} /$ day $+\mathrm{T}$ undecanoate $40 \mathrm{mg} /$ day. They showed that TG did not suffer any change in any of the groups, TC decreased in $20 \mathrm{mg} / \mathrm{dL}$ in the group of $\mathrm{E}$ and $\mathrm{T}$ and the LDL reduced significantly both groups, whereas HDL suffered reduction in both users of $\mathrm{E}$ and $\mathrm{T}$ and increase in the users of only E [20].

Farish et al studying 14 oophorectomized women treated with $50 \mathrm{mg}$ implants of $\mathrm{E}$ and 17 with implants of $\mathrm{E}$ and $\mathrm{T}$ (50 and $100 \mathrm{mg}$ respectively) during 6 months showed that the LDL reduced in both groups and LDL did not suffer modifications in the group $\mathrm{E}$ and $\mathrm{T}$ [31].

Sity six surgically menopaused women were followed during two years in Atlatne, U.S.A. by Watts et al. The group that used oral estrogen and metiltestosterone $(2.5 \mathrm{mg} /$ day $)$ had TC, HDL and TG reduced significantly [32].

The benefits of the use of androgens have been demonstrated in publications resulting from studies with a reduced number of patients, in non-probabilistic samples, and most of them observational. On the other hand, the results converge towards an improvement of the lipid profile and increase in the bone mineral density in the patients in post menopause. The greater limitation of these results lies on the difficulty on determining the isolated effects of the androgens once the studies showed results obtained through HT with E and androgens. Clinical rehearsals in comparison between the use of isolated $\mathrm{E}$ and $\mathrm{E}+\mathrm{T}$ shall clarify the impact of this combination under the lipid profile and bone protection in postmenopausal patients.

\section{References}

1. Britto R, Araujo L, Barbosa I, Silva L, Rocha S, Valente AP. Hormonal therapy with estradiol and testosterone implants: bone protection? Gynecol Endocrinol. 2011;27(2):96-100.

2. Collins P, Rosano GM, Jiang C, Lindsay D, Sarrel PM, Poole-Wilson PA. Cardiovascular protection by oestrogen--a calcium antagonist effect? Lancet. 1993;341(8855):1264-1265.

3. Jensen J. Effects of sex steroids on serum lipids and lipoproteins. Baillieres Clin Obstet Gynaecol. 1991;5(4):867-887.

4. La Vecchia C. Sex hormones and cardiovascular risk. Hum Reprod. 1992;7(2):162-167.

5. Rozenberg S, Liebens I, Vandromme J, Hotimsky A, Van Rijsselberge M. Cardiovascular protection by estrogen: a hemodynamic mechanism? Int J Fertil Menopausal Stud. 1994;39 Suppl 1:36-42.

6. Grodstein F, Stampfer M. The epidemiology of coronary heart disease and estrogen replacement in postmeno- pausal women. Prog Cardiovasc Dis. 1995;38(3):199210.

7. Colditz GA, Willett WC, Stampfer MJ, Rosner B, Speizer FE, Hennekens CH. Menopause and the risk of coronary heart disease in women. N Engl J Med. 1987;316(18):1105-1110.

8. Stampfer MJ, Colditz GA, Willett WC, Manson JE, Rosner B, Speizer FE, Hennekens CH. Postmenopausal estrogen therapy and cardiovascular disease. Ten-year follow-up from the nurses' health study. N Engl J Med. 1991;325(11):756-762.

9. Stampfer MJ, Grodstein F, Bechtel S. Postmenopausal estrogen and cardiovascular disease. Contemp Intern Med. 1994;6(9):47-56, 59.

10. Wassertheil-Smoller S, Hendrix SL, Limacher M, Heiss G, Kooperberg C, Baird A, Kotchen T, et al. Effect of estrogen plus progestin on stroke in postmenopausal women: the Women's Health Initiative: a randomized trial. JAMA. 2003;289(20):2673-2684.

11. Rossouw JE, Anderson GL, Prentice RL, LaCroix AZ, Kooperberg C, Stefanick ML, Jackson RD, et al. Risks and benefits of estrogen plus progestin in healthy postmenopausal women: principal results From the Women's Health Initiative randomized controlled trial. JAMA. 2002;288(3):321-333.

12. Rossouw JE, Prentice RL, Manson JE, Wu L, Barad D, Barnabei VM, Ko M, et al. Postmenopausal hormone therapy and risk of cardiovascular disease by age and years since menopause. JAMA. 2007;297(13):14651477.

13. Kurdoglu M, Yildirim M, Kurdoglu Z, Erdem A, Erdem M, Bilgihan A, Goktas B. Cardiovascular risk assessment with oxidised LDL measurement in postmenopausal women receiving intranasal estrogen replacement therapy. Gynecol Endocrinol. 2011;27(8):551-557.

14. Yoshida T, Takahashi K, Yamatani H, Takata K, Kurachi $\mathrm{H}$. Impact of surgical menopause on lipid and bone metabolism. Climacteric. 2011;14(4):445-452.

15. de Paula FJ, Soares JM, Jr., Haidar MA, de Lima GR, Baracat EC. The benefits of androgens combined with hormone replacement therapy regarding to patients with postmenopausal sexual symptoms. Maturitas. 2007;56(1):69-77.

16. Appleby L, Montgomery J. Effect of combined implants of oestradiol and testosterone on libido in postmenopausal women. Br Med J (Clin Res Ed). 1987;294(6584):1417-1418.

17. Montgomery JC, Appleby L, Brincat M, Versi E, Tapp A, Fenwick PB, Studd JW. Effect of oestrogen and testosterone implants on psychological disorders in the climacteric. Lancet. 1987;1(8528):297-299.

18. Panay N, Al-Azzawi F, Bouchard C, Davis SR, Eden J, Lodhi I, Rees M, et al. Testosterone treatment of HSDD in naturally menopausal women: the ADORE study. Cli- 
macteric. 2010;13(2):121-131.

19. Filho AM, Barbosa IC, Maia H, Jr., Genes CC, Coutinho EM. Effects of subdermal implants of estradiol and testosterone on the endometrium of postmenopausal women. Gynecol Endocrinol. 2007;23(9):511-517.

20. Zang H, Carlstrom K, Arner P, Hirschberg AL. Effects of treatment with testosterone alone or in combination with estrogen on insulin sensitivity in postmenopausal women. Fertil Steril. 2006;86(1):136-144.

21. Genazzani AR, Pluchino N. Androgen replacement therapy and cardiovascular function. Climacteric. 2009;12 Suppl 1:102-107.

22. Noyan V, Yucel A, Sagsoz N. The association of androgenic sex steroids with serum lipid levels in postmenopausal women. Acta Obstet Gynecol Scand. 2004;83(5):487-490.

23. Leao LM, Duarte MP, Silva DM, Bahia PR, Coeli CM, de Farias ML. Influence of methyltestosterone postmenopausal therapy on plasma lipids, inflammatory factors, glucose metabolism and visceral fat: a randomized study. Eur J Endocrinol. 2006;154(1):131-139.

24. Mudali S, Dobs AS, Ding J, Cauley JA, Szklo M, Golden SH. Endogenous postmenopausal hormones and serum lipids: the atherosclerosis risk in communities study. $\mathrm{J}$ Clin Endocrinol Metab. 2005;90(2):1202-1209.

25. Sherwin BB, Gelfand MM, Schucher R, Gabor J. Postmenopausal estrogen and androgen replacement and lipoprotein lipid concentrations. Am J Obstet Gynecol. 1987;156(2):414-419.

26. Garnett T, Studd J, Watson N, Savvas M. A cross-sectional study of the effects of long-term percutaneous hormone replacement therapy on bone density. Obstet
Gynecol. 1991;78(6):1002-1007.

27. Studd J, Savvas M, Waston N, Garnett T, Fogelman I, Cooper D. The relationship between plasma estradiol and the increase in bone density in postmenopausal women after treatment with subcutaneous hormone implants. Am J Obstet Gynecol. 1990;163(5 Pt 1):14741479.

28. Savvas M, Studd JW, Norman S, Leather AT, Garnett TJ, Fogelman I. Increase in bone mass after one year of percutaneous oestradiol and testosterone implants in post-menopausal women who have previously received long-term oral oestrogens. Br J Obstet Gynaecol. 1992;99(9):757-760.

29. Davis SR, McCloud P, Strauss BJ, Burger H. Testosterone enhances estradiol's effects on postmenopausal bone density and sexuality. Maturitas. 2008;61(1-2):1726.

30. Castelo-Branco C, Vicente JJ, Figueras F, Sanjuan A, Martinez de Osaba MJ, Casals E, Pons F, et al. Comparative effects of estrogens plus androgens and tibolone on bone, lipid pattern and sexuality in postmenopausal women. Maturitas. 2000;34(2):161-168.

31. Farish E, Fletcher CD, Hart DM, Azzawi FA, Abdalla HI, Gray CE. The effects of hormone implants on serum lipoproteins and steroid hormones in bilaterally oophorectomised women. Acta Endocrinol (Copenh). 1984;106(1):116-120.

32. Watts NB, Notelovitz M, Timmons MC, Addison WA, Wiita B, Downey LJ. Comparison of oral estrogens and estrogens plus androgen on bone mineral density, menopausal symptoms, and lipid-lipoprotein profiles in surgical menopause. Obstet Gynecol. 1995;85(4):529-537. 